\title{
Assessment of Effectiveness of Government Accounting and Budgeting System (GABS) in Botswana
}

\author{
N. Tonkope \\ Department of Accounting and Finance, Faculty of Business, University of Botswana \\ Gaborone, Botswana
}

Pritika Singh Baliyan (Corresponding author)

Department of Accounting and Finance, Faculty of Business, University of Botswana

Gaborone, Botswana

Email: baliyanp@mopipi.ub.bw

G. Tobedza

Department of Accounting and Finance, Faculty of Business, University of Botswana

Gaborone, Botswana

Received: February 11, 2017 Accepted: February 28, 2017 Published: March 09, 2017

doi:10.5296/ijafr.v7i1.10709 URL: http://dx.doi.org/10.5296/ijafr.v7i1.10709

\begin{abstract}
An effective implementation of Government Accounting and Budgeting System (GABS) is critical to the success of any government business. This mixed method study investigated the effectiveness of Government Accounting and Budgeting System in the public sector of Botswana by analyzing the procedures, benefits, and challenges of the system. An exploratory research design was used whereby a sample of sixty respondents was selected from six government departments in Botswana using a stratified proportionate sampling method. Primary and secondary data collected for the study was analyzed using frequency, percentages, correlation and content analysis. The findings indicated that government accounting and budgeting system promotes efficiency in the public sector, as its introduction is positively related to accountability and decision making in an organization. This system
\end{abstract}




\section{MInstitute Macrothink $_{\text {Int }}$}

International Journal of Accounting and Financial Reporting ISSN 2162-3082 2017, Vol. 7, No. 1

has been effective as it has improved service delivery and saves time. Network connectivity, lack of skilled manpower and access of system by outsiders were the three major challenges whereas increase in qualified personnel, increase in training on GABS and a reliable backups system were determined major strategies to improve the system.

Keywords: Accounting system, Budgeting system, Computerized accounting system, Government accounting, GABS

\section{Introduction}

The last two decades have witnessed fundamental changes in the public sector of developed countries such as New Zealand, United Kingdom and Australia. The Asia-Pacific region countries including South Korea, Taiwan, Hong Kong and Singapore have also experienced extraordinary reform initiatives in the public sector management such as resources use efficiency and decentralized planning. These reform initiatives were not limited to developed countries but developing countries such as Botswana, Nigeria, South Africa and Tanzania are not left behind in their efforts to introduce fundamental reforms in their public sectors. While it has been established that a majority of developing countries are initiating such reforms, reports still show that some countries are still using the traditional method of government accounting systems, that is, cash-based system, and traditional budgeting system to manage the government business. The continual use of traditional accounting and budgeting system led to facing challenges in their financial management system, as they can no longer provide information required by an efficient and effective government system.

Accounting system refers to the organized and computerized set of rules used to determine the way in which income and expenses of the business are recorded, procedures, controls established to gather, record, classify, analyze, summarize, interpret, and present accurate and timely fiscal information for decisions of management (http://www.businessdictionary.com/definitions/establish.html). It is referred to the way in which records of accounting are set and used within a business (Okoye \& Oghoghomeh, 2011). Budgeting systems are regarded more in terms of planning and enacting a fiscal plan. However, these planning and enactment processes are dependent upon the accounting of pastyear and current-year expenditures, revenues, transfers and prior year adjustments (IPSAS Report, 1997). The public sector consists of governments and all publicly controlled or publicly funded agencies, enterprises, and other entities that deliver public programs, goods, or services (Institute of Internal Auditors Guidance (IIAG), 2011). Government accounting is the process of recording, analyzing, classifying, summarizing, communicating and interpreting financial information about government comprehensively and in details reflecting transactions and other economic events involving the receipt, spending, transfer, usability and disposition of assets and liabilities (IPSAS report, 1997). Public sector Accounting refers to an accounting method applied to non-profit pursuing entities in the public sector including central and local governments and quasi-governmental special corporations for which the size of profits does not provide an effective measurement for evaluating performance (Lewis \& Pendrill, 1999). 


\section{Ml Macrothink}

International Journal of Accounting and Financial Reporting ISSN 2162-3082 2017, Vol. 7, No. 1

The public sector accounting systemizing alternative to the traditional method of government accounting system, and offers better reports on government activities. It is validated as a tool for promoting efficiency in the public sector. Its advent also led to improvements and efficiency of resource management, effectiveness in policy delivery, transparency of information and accountability to parliament and the public. According to Monteiro and Gomes (2012), budgets can be classified using the accounting process for resources allocation, thus dividing budgets using cash basis or accrual basis. Botswana government has adopted cash basis method despite the use of GABS. Botswana is committed to introducing accrual accounting for the government to utilize the International Public Sector Accounting Standards driven by many factors such as financial crisis which affected many countries globally in 2008 (Motsamai, 2014). Accrual budgeting is the specification of budgetary expenditure authorizations and revenue estimates in terms of accrual accounting measures, which is said to be improving expenditure effectiveness, efficiency and decision making with respect to assets (Robinson, 2009). Motsamai (2014) stated that government aimed at providing a strong understanding of costs and revenues which includes those which may not arise in the current financial year, which could not be provided by the cash basis accounting. This also is an effort for the government to improve the effectiveness of Government Accounting and Budgeting System.

Based on these above advantages, the government of Botswana adopted public sector accounting system known as Government Accounting and Budgeting System (GABS) as a strategy for improving the financial management procedures in the country through the Ministry of Finance and Development Planning in 2002 (Ministry of Finance Planning and Development Report (MFPD) Report, 2007). This was due to the inherent constraints and disadvantages associated with the previous system that was manually operated. To address the failure of the previous system, the Minister of Finance and Development Planning proposed a new Government Accounting and Budgeting System (GABS) that allowed decentralization of data entry, reliability, accuracy and generation of timely information and provide additional functionality to work (MFDP Report, 2007). The new system was proposed to improve: efficiency of resource management, effectiveness in policy delivery, transparency of information and accountability of government to the public. Just like other countries, Botswana has previously adopted International Public Sector Accounting Standards (IPSAS) that made her to introduce accrual accounting for government operation. The system also helps the government to identify which accounting elements are to be recognized and how they can be measured (Motsamai, 2014).

The government accounting and budgeting system was linked to many government sub-units in Botswana. This is not limited to Accounting and Budgeting functions but includes Computerized Government Payroll, Pensions and Passages System (GPPPS) for purposes of payroll and pension's functions, as well as Supply Warehousing and Inventory Management System (SWIMS) for inventory management (MFPD Report, 2007). All these systems were built on oracle application and were rolled out to the rest of the departments in the country. GABS project stakeholders include; the public, contractors, government funded schools and orphanages, end users of the system, ICT association, Bank of Botswana and interfacing 


\section{MInstitute Macrothink $_{\text {Int }}$}

International Journal of Accounting and Financial Reporting ISSN 2162-3082 2017, Vol. 7, No. 1

systems such as vehicle registration system, department of suppliers system, Central medical stores and Directorate of Public Service Management. The adoption of GABS in 2002 in Botswana's Public Finance Management (PFM) witnessed a high level of predictability and transparency, coupled with limited incidences of corruption. However, given the huge amount of benefits that are associated with GABS in the public sector, its implementation is hindered by technological and social problems (Marivic, 2009; Nash \& Nealy, 2003). The fundamental features of the new financial measurement systems and the problems they have created lead to the assessment of GABS in the public sector of Botswana. The review of literature on GABS highlighted that few researches were done on its impact in the public sectors of developing countries in Africa, particularly Botswana (MFPD Report, 2007). Therefore, there is a need to assess the system in government departments for its effectiveness and implementation so that required significant changes in policy, research and professional practice can be made.

\subsection{Statement of the Problem}

The long-term goal of government accounting and budgeting system (GABS) in the public sector is to improve effectiveness in the day to day operation of government business. Despite the globalization of government accounting and budgeting system as a means for promoting efficiency and effectiveness in the public and private sectors, there is a significant concern about its adaptability and effectiveness in the public sector of Botswana. This is due to its newness as a financial management tool, and because it is not properly implemented as evidenced by registered high instances of delay, inaccurate reporting, misrepresentation and wrong balances of its application in government business (MFPD Report, 2007). Though, similar studies have been done in the past on the private sectors (Tajani \& Mohammed, 2013), this did not specifically emphasize on the public sector but highlighted that public sector has the highest number of employees and users of GABS in the country (MFPD Report, 2007).

Considering the fact that this system has just been recently adopted as a tool to improve the quality of financial reports, transparency and accountability in government services in Botswana (IPSAS Board Report, 1993), debates about its effectiveness continue to rage on, as there are serious concerns regarding its impact and benefit son government business. Moreover, very limited research on GABS, particularly its effectiveness in public sector has been conducted. This study intended to determine valuable information on the implementation of GABS in the public service of Botswana which could help in guiding the future direction of the government accounting and budgeting system in Botswana. Therefore, the present study investigates the effectiveness of GABS in the public sector of Botswana by specifically analyzing its procedures, benefits, challenges and effectiveness.

\subsection{Aim and objectives of the Study}

The aim of this study was to investigate the effectiveness of Government Accounting and Budgeting System in the public sector of Botswana. The specific objectives of the study were as follows: 


\section{MInstitute Macrothink $_{\text {Int }}^{\text {Intis }}$}

International Journal of Accounting and Financial Reporting

ISSN 2162-3082 2017, Vol. 7, No. 1

i). To identify whether the Government Accounting and Budgeting System benefits users in the public sector of Botswana.

ii). To explore the user's perceptions on the use and effectiveness of the Government Accounting and Budgeting System in the public sector of Botswana.

iii) To identify challenges associated with the Government Accounting and Budgeting System in various government departments in Botswana.

iv) To identify the appropriate strategies for improving the effectiveness of Government Accounting and Budgeting System in the public sector of Botswana.

\subsection{Research Questions}

In order to achieve the objectives of this research, the following are research questions answered:

i). Does the Government Accounting and Budgeting Systems benefit the users in the public sector of Botswana?

ii). What are the perceptions of users on the use and effectiveness of the Government Accounting and Budgeting System in the public sector of Botswana?

iii). What are the challenges in the application of government accounting and budgeting system in various government/public departments in Botswana?

iv). What strategies can be employed to improve the effectiveness of Government Accounting and Budgeting System in the public sector of Botswana?

\section{Literature Review}

\subsection{Overview of Accounting}

Accounting is termed as a process of reporting, recording and analyzing of financial data in a business organization (Wahab, 2003). This is also defined as the process of identifying, gauging, and communicating economic data (International Federation of Accountants - IFAC, 2011; Wood \& Sangster, 2012). Accounting takes an important role in organizational management and development as is essential for all organizations to keep track record of financial information relating to their business activities. Accounting also connotes different processes of operation, while some of its processes are simple to operate; others are very complex and cumbersome. However, with the expansion and recent developments in technology, global market expansion, e-commerce, and changes in business management, companies need to maintain highly accurate and up-to-date accounting, inventory and statutory records (International Federation of Accountants - IFAC, 2011).

\subsection{Private and Public Sector Accounting System}

There are significant difference in the private and public sector accounting. Public sector accounting is referred to as accounting systems that are applied to non-profit pursuing entities, such as central and local governments and quasi-governmental special corporations. 


\section{Mll Macrothink}

International Journal of Accounting and Financial Reporting ISSN 2162-3082 2017, Vol. 7, No. 1

This kind of organization does not provide an effective measurement for evaluating performance (Carol, 2002). On the other hand, private sector accounting involves the setting up of systems and recording of business transactions that are aggregated into financial statements. The difference between these two sectors (private and public) is related to the environment in which they operate (Marivic, 2009). While public sector accounting focuses on different goals, the private sector entities' emphasis is only on one goal of making profit (Carol, 2002). Moreover, public accounting systems give more attention to financial accountability. This is well demonstrated through compliance with budgetary context in their use of resources. However, looking at the private sector, it clearly evident that budget is not a tool in their financial planning and it is not mandatory to comply with it (Carol, 2002).

Additionally, the uniqueness of government accounting does not exclude the use of the double entry accounting system. This is quite different from the private accounting where it is a common practice to try to arrive at a net income result (Marivic, 2009). However, the objective of government accounting system is applied to government bodies in two major categories: the accounting of activities for accountability purposes, that is, the governmental accounting system way of measuring accounting is different from that of private sector accounting. Secondly, government accounting system measures flows of financial resources, instead of the economic resources (Carol, 2002). However, revenue is recognized when there are funds available to pay the entity debts and expenses. It is also recognized when there is a reduction on current resources instead of increasing revenue earned and expenses incurred (Marivic, 2009).

\subsection{Budgeting systems}

Budgeting system is the process of planning and ratifying fiscal plans and it is generally regarded as a significant environmental feature of government organizations (Carol, 2002). This is not only essential to public management, but also serves as a central piece of government accounting. Wildavsky (1984) highlighted the central role of budgeting systems in the management of public sector by suggesting that budgeting is the lifeblood of the government and the financial reflection of what the government does or intends to do. Therefore, regardless of the technique to be used, a budget should express what the government activities ought to be during a particular period of time in the light of limited resources (Ball, Dale, Eggers, \& Sacco, 2000; Barton, 2009). In addition, Doost (1984) and Bargues (1992) emphasized the significant of budgeting system by explaining that budget is a tool for planning and controlling expenses, achievements and programs in government services. Besides, they also suggested that budgeting is a means of coordinating governmental activities that imply financial consequences. However, if this control activity is acknowledged as important in a profit oriented business entity, it is also recognized as essential in governmental units (Barton, 2009). This is due to the fact that in public sector; budget embraces authorized expenditures and estimated revenues.

Jones and Pendlebury (2000) emphasized the significant role of budgeting in managerial planning and control processes by suggesting the process as an important link that ensures the attainment of organizational achievement and plans. Budgeting provides a critical link 
between the two processes, i.e., managerial planning and control processes (Chan, 2001). In a well-organized entity, long-term and medium-term plans are evidently important, but no matter how intricate and complete these may be, they only express intentions. However, it is only when these intentions are integrated into the annual budget that they become firm commitments, with funds being allocated to enable their achievement (Ball, Dale, Eggers, \& Sacco, 2000; Barton, 2009; Chan, 2001). Additionally, budget creates and enforces accountability in government business at three levels: from civil servants at lower level to ministers, from executive to parliament, and finally from the government, i.e., legislative, executive and judicial components to the electorate(Chan, 2001). This shows that through budgetary process, government resources are allocated to different public segment of the country. This further emphasizes budgetary system as a management tool for governmental entities. However, regardless of its role and usefulness in governmental accounting, budget remains the most important government accounting financial document, and acknowledged as a tool for forecasting the resources expected to be expended (not just paid), as well as sources of financing that convey information other than cash-flows, i.e. accrual-based system (Robinson, 2009).

\subsection{Public and private budgeting system}

Public and private budgeting is different in practice and seen from different perspectives (Lancouch, 2003). These perspectives include: accounting, profit, context and decisions. The applicability and practice of accounting in both private and public sector financial management differ significantly. For instance, the Generally Accepted Accounting Principles (GAAP) mandates private sector financial managers and accountants to use accounting methodology. This method includes double-entry accounting method that ensures and promotes financial accuracy and uniformity in an organization (Lancouch, 2003). The method is employed in public sectors for proper financial management. Also, it is common in the area of budgeting where accrual accounting method is not necessarily imposed on financial managers in public sector (Lancouch, 2003). Government agencies are not necessarily profitdriven in the same way as private businesses and corporations. Financial managers in private sectors are motivated by profits and forced to keep profitability at minimum level, whereas in public sector, financial managers do not necessarily have to keep the bottom line. They may perhaps, be task-oriented or driven by some other motivating forces relating to the organizational goals and objectives (Lancouch, 2003). Another fundamental difference between public and private budgeting systems is the context in which it operates (Lancouch, 2003). The context of an organization influence how an organization works and what approach is appropriate for the organizational goals. For instance, in the private sector, financial managers are driven by profit; as a result they must get things done in order to keep the bottom line. On the other hand, financial managers in the public sectors are prevented from acting with a great deal of independence as they face various limitations. For instance in the public sector, financial managers are subjected to legislative and regulatory constraints that prevent autonomous action. Besides, the political framework in the public sector may influence the bureaucratic financial managers to go against the decision of the elected officials on different occasion, therefore, causing major hindrance on its effectiveness on the 
job (Lancouch, 2003).

\subsection{Government Accounting and Budgeting System}

Different scholars have defined the government accounting and budgeting system differently. According to Wahab (2003), a government accounting system is a process that replaces a manual system, or accountant in recording and processing financial transactions in an organization. Though, research highlighted the difference between accounting and budgeting systems, the two concepts are somehow related. The key difference between budget and accounting is that, budget is a plan for where a business wants to go, while accounting focuses on the recording, classifying and summarizing of transaction for reporting purposes. In the public sector for example, accounting as a concept is a technique applied to non-profit making organization. This comprising the central and local governments, as well as the quasigovernmental special corporations for which the size of profits does not provide an effective measurement for evaluating performance. The system permits managers and other end users to analyze the financial health of an organization and take necessary action in the light of that information. Though, this system is designed to be fully customizable, its primary components remain the same across different types of systems (Wahab, 2003).

Government accounting system is used as a tool to input, process, store and output accounting information of financial reports. It adds all record transactions that regularly deal with financial position and performance of a unit (Meigs \& Mary, 1998).Further, government accounting system records financial information on business transactions. The system serves as a tool for organizing, summarizing, analyzing, interpreting and communicating with stakeholders through the use of computer based systems such as accounting packages (Marivic, 2009). Since keeping accurate accounting records is a vital part of any organization, GABS is employed to facilitate financial information inflows of accounting tasks, such as database recording and report. Putting together all the definitions above, a conclusion can be made that a government accounting and budgeting system is a delivery system of accounting information that offers reliable accounting information to users and protect the organization from possible risks arising from the abuse of accounting data and system among others.

\subsection{Objectives of Government Accounting System}

"The objectives of government accounting system include: Monitoring of the budget execution process; accountability; capital maintenance; financial viability, providing information for the management decision-making process; external user's decision-making process; and cost of the services provided; disclosure information on the financial position; inventory disclosure; economic surplus or deficit; recording budgetary execution; control of efficiency and effectiveness" (Montesino, 1995, p.172). These objectives are broadly embraced by the Botswana government, as they adopted similar objectives, such as increasing the ability to carry out central control and monitoring of expenditure and receipts in the Ministries and Departments, provide online and up to date information on the government cash position, profitable, financial and operational performance, reduce the replication of maintaining the same information, faster processing of budget preparation, accounts closing and other transactions processing and improve the ability to demonstrate 


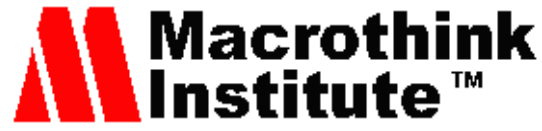

International Journal of Accounting and Financial Reporting

ISSN 2162-3082

2017, Vol. 7, No. 1

accountability to donors and to the public by having proper audit track of transactions in the system (MFDP Report, 2007, p.6). Furthermore, Alhosban and Maqableh (2014) outlined various factors that increase the capacity of the computerized accounting system, thus resulting in the reduction of costs.

\subsection{Advantages of Government Accounting and Budgeting System}

According to Lewis and Pendrill (1999), there are many benefits of government accounting and budgeting systems as compared to the manual system. These benefits include an increase in productivity, accuracy, time savings and organization of financial information. Bargues (1992) stated that government accounting system aims at giving a true and fair view of the government assets and liabilities, fiscal conditions and results of the entity. It provides useful, reasonable information on costs and revenues of responsibility centers and services provided by several entities and bodies. It permits the integration of the public sector economicfinancial information within the macro-economic accounts at regional and national level. It also, enables administrators to assure and report upon compliance with financial-related legal provisions-legal restrictions on the resources utilization (i.e. spending limits). Government Accounting Standard Board (GASB, 1997) also highlighted the similar functions.

The budgetary process provides necessary control mechanisms in the public sector, and it replaced the role that business played in the private sector Drebin (1981). Lewis and Pendrill (1999) argued that employees who have access to government accounting and budgeting systems can work more quickly and enjoy increased productivity. This means that using GABS allows employees to make changes faster than adjusting a printed ledger or chart. It also offers employee's opportunity to spend less time spent processing data and more time to analyze the data and get the most use of it (Lewis \& Pendrill, 1999; Marivic, 2009). Wood and Sangster (1999); Elekwa and Innocent (2013) also concur that the use of computerized accounting increases the speed at which accounting is done and that the process help employees to retrieve balance sheets, income statement or other accounting reports at any moment.

Further, Wood and Sangster (2009) suggested that government accounting system allow managers to easily identify and solve problems instantly. Additionally, Indira (2008) stated that GABS promote business performance. He stated that the process integrate application that transforms the business processes with the performance enhancing features, and this encompasses accounting, inventory control, reporting and statutory processes. Processing of government accounting using a computer helps the finance department or ministry of finance to have a good employee payroll system and helped to speed up employee payments. According to Elekwa and Innocent (2013) pay-rolling is the process of listing names of employees by either private or public sector which shows the amount of money to be paid to an individual employee. Therefore, the application of GABS in carrying out accounting activities allows the processing of volumes and volumes of information and promotes information accuracy (Manani, 2013). 
Furthermore, the GABS promote employees performance as the government accounting packages can quickly generate all types of reports needed by bosses and the top management, i.e., in the areas of budget analysis and variance analysis. He also argued that by using GABS, data processing and analysis are faster and more accurate, therefore, meeting the managers need for accuracy and timely information for decision making (McBride, 2000). Use of GABS in an organization save time (Wahab, 2003). The system also makes inputting accounting information simple. Transactions are entered into the system and the system posts transactions accordingly (Wahab, 2003). Further, McRae (1998) indicated that government accounting and budgeting systems consolidate information channels as files that were previously been duplicated by several departments are now consolidated into a single file within a short period of time.

Ilias and Zainudin (2013) stated that Information Communication Technology (ICT) and Computerized Accounting Systems (CAS) have relieved the government from keeping bulky information which increase rapidly and becomes a problem when using manual system. The government accounting and budgeting system helps businesses in reducing a lot of paper work and stay organized. When information is entered into the system, it can be retrieved easily whenever needed (Carls, Wailes \& Fess, 1999). Managers also easily satisfy statutory and donor reporting requirements such as profit and loss account, balance sheet and customized reporting through the use of government accounting and budgeting systems (McBride, 2000). The system allows quick access to information with less effort. The use of government accounting and budgeting systems eased auditing and promote access to required information such as cheque numbers, payments, and other transactions. The system also help to reduce the time spent on accessing this information and documentation during auditing (McBride, 2000).

GABS gives organizations the capability to provide customers with better services, and also optimize available resources (Hingarh \& Ahmed, 2013). The review of literature on the current study showed an evidence of positive relationships between GABS and efficiency in government services (Wahab, 2003) which refers that the use of the system permits managers and other end users to analyze the financial health of an organization and take necessary actions in the light of that information (Wahab, 2003). In addition, government accounting and budgeting system was found to be important, as it aided the organizational use of financial reporting and evaluated the amounts, timing and uncertainties of cash flows. Also the system helped in furnishing information about government economic resources, claims against those resources, owners' equity and changes in the resources (Wood \& Sangster, 1999). Overall, government accounting and budgeting system promotes service delivery; record financial information on business transactions and serves as a tool to organize; summarize; analyze; interpret and communicate the organizational goals (Marivic, 2009).

\subsection{The Impact of Government Accounting System on Financial Reporting}

Financial reporting is the process of presenting financial information or data about a company's financial position, operating performance and its flow of funds for an accounting period (Van, 2005). Government accounting and budgeting systems is also credited for their 


\section{Ml Macrothink}

International Journal of Accounting and Financial Reporting ISSN 2162-3082 2017, Vol. 7, No. 1

quick processing speed and large storage capacity. For example, effective use of government accounting and budgeting systems promote and ensure up to date account balance that aid management in their decision making (Lancouch, 2003). The system also saves time on transaction hence, leading to accurate and quality of financial reporting and reliability of information (Lewis \& Pendrill, 1999). Thus the influence of accounting systems depends on the end user's satisfaction. This position was supported by Mihir (2002) when he highlighted that higher end user's satisfaction leads to positive attitude that in turn increases the voluntary usage of the system. Therefore, the quality of accounting information and performance of the accounting systems is a great concern to management (Nash \& Healy, 2003).

Also, government accounting and budgeting system aid the use of financial reporting by evaluating the amounts, timing and uncertainties of cash flows. It also help in furnishing information about the entity's economic resources, claims against those resources, owners' equity and changes in the resources and claims (Wood and Sangster,1999). Indira (2008) emphasized that GABS provide information about financial performance and promote effective management. The system also helped managers and directors themselves in making good decisions on behalf of the owners (Indira, 2008). This further shows that accounting information is a necessary tool for various parties to make accurate and rational decision in an organization (Indira, 2008).

Furthermore, Turner (2000) contends that neutrality is essential for effective GABS. He maintained that accounting information should not be selected to benefit one class and neglect others which raise questions on verification, neutrality and faithfulness of the system. Relevance is also a very important characteristic of quality. Wood and Sangster (2012) indicated that financial information is relevant if it is capable of making a difference in decisions made by helping users to form predictions about the outcomes of the past, present and future events, either to confirm or correct prior expectations. Comparability is another characteristic of quality information. Wood and Sangster (1999); Wood and Sangster (2012) emphasized that users must be able to compare the financial statements of the enterprise over time in order to identify trends in its financial position and performance. As a result of perishability of accounting information, Indira (2008) highlighted timeliness as an important characteristic of quality financial information. Therefore, to benefit users, financial information must be presented at the right time otherwise it loses relevance.

\subsection{Challenges of Government Accounting and Budgeting System}

The government accounting and budgeting system is associated with several limitations. These limitations include costs and human need (Nash \& Healy, 2003) to update a traditional organization, government increase government expenditure and costs. Also, reorganization of personnel and buying of accounting software requires organization spending, such as investment in new computers, regular software updates, and training and a new recruitment policy and employment of qualified professionals who are familiar with the operation of the system. Besides, as Accounting Information systems is automated; there is a need for accountants to acquire necessary skills to effectively utilize the system (Dalci \& Tanis, n.d). Further, Tarmitti, Rashid, Deris and Roni (2013) argued that untrained personnel are likely to 


\section{Ml Macrothink}

International Journal of Accounting and Financial Reporting ISSN 2162-3082 2017, Vol. 7, No. 1

make error when entering information in the system, thus leading to disaster. In addition, government accounting and budgeting system requires human beings to attain effectiveness and despite its advancing complexity, the system cannot fully replace human resources (Nash \& Healy, 2003). In this regard, GABS requires judgment decisions and improvisational thought that cannot be found in sophisticated piece of software (Nash \& Healy, 2003). Human beings need to understand the changing landscape of legal regulations and company policies, some of which find their way into new versions of government accounting systems and control how employees use their computerized tool. All these services, therefore, cannot be done by computers alone; hence, there is a need for human resources.

One of the challenges is how to meet the projected needs of the stakeholders. According to Batt (2014) budgets are created based on requests from competing stakeholders, each justifying their projected expenditures based on their departmental needs rather than the overall goals of the organization. Despite the advent of powerful computer networks and multi-layered models, budgeting remains prolonged and expensive as government and private organizations budgeting approach consistently show higher rates of inaccurate assumptions, a massive time commitment and tedious manual input (McRae, 1998). However, if this is not properly managed, it can affect the organizational achievement and goals. Batt (2014) expressed that budgeting system does not adequately link financial investments to results or outcomes. This limits the ability for in-depth analysis and understanding of the real Return on Investment (ROI) for any given line of business or initiative.

Despite the significant of human need in the use of GABS, there is a risk of improper human intervention regarding programs and files. For example, one may temper with programs and program based records in order to forge accounting information. This may result in distortion of information that may be useful for decision making in an organization (Meigs, 1986). This was supported by MFDP Report (2007) in which the capability of the operational staff to run the system is questioned due to high number of errors noticed in the operation that are related to improper data entry skills and staff incompetence. This inaccuracy of data has significant effects on the effectiveness of the GABS, therefore, adequate steps must be taken to avoid such errors in computerized accounting system and prevent theft, fraud and exploitation of information (Wood \& Sangster, 2012).

Another problem associated with the use of government accounting system is network problems (Wahab, 2003). Review of literature showed that some of the countries using government accounting and budgeting system have long been experiencing network problems. This means that the network provided is not up to the mark (MFDP Report, 2007). A network is essentially a collection of information processing and communication resources that connect different information system assets, enabling them to share, access, and transmit information and data. It is important to control access of information system by both internal and external users to avoid compromising network security. Connections which are not secure can seriously compromise the information systems of the organization as a whole. Connections should be protected to avoid compromising the information system of the entire organization. Network and network services usage should not be left entirely for operational discretion, rather, a policy should be used to govern it (Hingarh \& Mahmed, 2013). 
Another challenge facing the effectiveness of government accounting and budgeting system is competence (IPSAS Report, 1997). With the growing complexity of the financial sector and the emergence of new and sophisticated financial instruments, there is a need for knowledge based professionals to keep pace with these emerging practices and innovations. According to Hingarh and Ahmed (2013), abuse of information systems are evident in various ways include damage of assets, theft of assets, modification of assets, privacy violation of data, disruption of operations and, unauthorized use of assets.

\subsection{Strategies for improving the effectiveness of Government Accounting System}

However, regarding the challenges facing the use of GABS in public sector, significant association was established between costs, human need and GABS effectiveness (Nash \& Healy, (2003). Therefore, by updating a traditional organization, (i.e., government ministry), introduction of GABS increased level of government expenditure and costs used in maintaining such expenditure, especially in a larger business. Further, review of literature confirmed reorganization of personnel and organizational spending, such as investment in new computers, regular software updates, training, new recruitment policy and employment of qualified professionals who are familiar with the operation of the system, as impeding the effectiveness of GABS in public sector (Tarmitti, Rashid, Deris \& Roni, 2013) and therefore, improvement in these areas can be effective strategies for improving the effectiveness of GABS.

In order to manage business and finance, there is need to improve the financial reporting process and management. This implies that organizations should ensure that they promote the use of up to date and complete International Financial Reporting Standards (IFRS) in their preparation and presentation of financial statements and ensure that they comply with the set standards and governing regulations (Wood\& Sangster, 1999). Also, firms should also ensure public availability of full sets of financial statements including notes for public interest entities rather than producing a summary of the financial reports to the stakeholders (Indira, 2008). Furthermore, organizations should ensure that they recruit skilled professionals to handle its accounting and offer routine training to the employees in the field of accounting basing on the changing environment (Michael \& Miller 2005).

\section{Methodology}

\subsection{Research Design}

A mixed method approach was adopted to gain deeper insight into the problem under investigation. This design is used when qualitative methodology is used to increase the generalisation of quantitative results (Harwell, 2011). As a result, this study applied both quantitative and qualitative methods by using concurrent mixed methods designs (Creswell, Plano Clark, Gutmann \& Hanson, 2008; Teddlie \& Tashakkori, 2009; Johnson, Onwuegbuzie \& Turner, 2007).

The first phase of this study was based on quantitative design where survey was conducted for data collection. The study aimed to investigate the effectiveness of Government Accounting and Budgeting system (GABS) in the public sector of Botswana and to explore 


\section{Macrothink}

International Journal of Accounting and Financial Reporting ISSN 2162-3082 2017, Vol. 7, No. 1

whetherthe system influenced the efficiency of resource management, policy delivery, and transparency of information and accountability in government business. As such, quantitative design (survey) was deemed suitable to address the research questions generated in this study. The second phase used the qualitative design whereby interview was conducted to explore the perceptions of employees in the public sector about the effectiveness of the Government Accounting and Budgeting system (GABS). This allowed the researcher a deeper understanding of the problem other than generalizing the findings across the population by obtaining information on an in-depth nature aspiring to impressions, desires, observations, motivations drives and stimulations (Saunders, Lewis \& Thornhill, 2000).

\subsection{Population and Sampling of the study}

A population of this study consists of all the subjects of study or a body of people or collection of items under observation (Collins \& Hussey, 2003) while sampling is the process of selecting a group of subjects of study in a way that ensures full representation of the larger group (Yount, 2006). The population of the study was 300 direct users of GABS in selected government departments in Botswana. The users included Accountant General, System Support staff, bursars from government schools, supplies officers, revenue staff and some heads of departments who are termed to be authorizing officers in the six government departments.

It was impossible to interview and collect information from every employee in the public sector of Botswana due to time and cost, hence a sample was drawn from this population through sampling. A sample can be defined as a subgroup or part of a population. There should be a minimum sample size for any target population which should be estimated at an acceptable level of accuracy (Saunders, Lewis \& Thornhill, 2007). Sampling is a process of selecting subjects that are representative of the population being studied (Saunders et al., 2000). An initial interview was first held with one senior accountant and procurement manager from the accountant general's office (GABS support office) to source out information on the department using GABS at the initial stage of the study. Based on their feedback, six departments out of 15 departments from different ministries were selected. A total of 60 officers were selected from six departments through stratified random sampling method. In each department, the researcher particularly included both senior officers (managers called authorizing officers) and junior officers in the sample. The sampled officers included the officers from accounting and finance department including revenue officers, department of transport, department of procurement and logistics, accounts officers and bursar's from education department, health department and agriculture. The sampling plan is presented in Table 1. 
Table 1: Sampling plan

Department Population Sample size

Finance $\quad 15030$

Education $\quad 40 \quad 8$

Transport $\quad 30 \quad 6$

Procurement and logistics 306

Agriculture $\quad 30 \quad 6$

Health $\quad 20 \quad 4$

TOTAL $\quad 30060$

\subsection{Data Collection Procedures}

Data for this study was collected in two phases. The first phase involved the collection of quantitative data whereby a survey questionnaire was administered to senior and junior staffs including bursars, accounts officers and other staff members in various government departments. The second phase was to collect qualitative data whereby personal interviews were carried out to gather in-depth information and also to explore the experience of senior and junior employees on the effectiveness of the Government Accounting and Budgeting Systems (GABS). Moreover, these two phases of the study were in tandem triangulated in order to consolidate and validate the findings of the study. According to Morgan (1998), Concurrent Triangulation Design method involves the use of two methods to cross validate or corroborate findings within a single study.

Data for the study was collected from both primary and secondary sources. The primary data was collected through semi-structured interview and administered survey questionnaires on the views and experiences of senior (Support system, Chief Administration Officers, Head Teachers, Senior Bursars, Senior Revenue Officers and Senior Supply Officers) and junior staffs(Teachers, Supplies Officers, Administration Officers, Bursars and other auxiliary staff) in the public sector of Botswana. Primary data was collected from respondents through the use of structured questionnaire. Data collection instrument used in this study consists of two sections, the first section consist of demographics information on the participants' employees, while the second section consist of closed questions and the third section consists of dichotomous where closed ended questions such as "yes or no" questions were asked, a 5point likert scale questions and open ended questions. The second section of the instrument contains items in the areas of government accounting and budgeting systems. The questions asked were dichotomous where 'yes' and 'no' and 'agree', 'disagree' and neutral were used, 


\section{Macrothink}

International Journal of Accounting and Financial Reporting

ISSN 2162-3082

2017, Vol. 7, No. 1

thus closed and open ended questions were used. Secondary data was secondary data by reviewing the key documents included government accounting and budgeting report, GABS manual and other reports generated by GABS.

\subsection{Data Analysis}

The data was analyzed using the Statistical Package for the Social Science (SPSS) version 23. Descriptive and inferential statistics were used as tools for analyzing the data of this study (Manani, 2013). Thee quantitative analysis included frequency, percentages and correlation. The responses from the interviews were analyzed and subjected to content analysis to identify the common and emerging themes and sub-themes. Qualitative analysis was facilitated thematically using semi-structured questions to gauge the views of senior and junior staff members using government accounting and budgeting system in the public sector of Botswana.

The piloting of the instrument was done in order to test for the reliability. Piloting the questionnaire is regarded as an important stage of data collection (Mertens, Sethosa, 2001). Furthermore, Cronbach's alpha reliability statistic was also computed to test the reliability of the scales. Based on Nunnaly (1978), .70 and above value is an acceptable reliability coefficient in most social science research situations; 17 items (yes or no and agree, neutral and disagree) were tested and all the scales' reliability coefficients were .739 or higher. the questionnaire was considered reliable.

The questionnaire was reviewed in order to test for the validity. The instrument was sent to 12 staffs of related department for reviewing. The instrument was validated by experts and professionals in the area of accounting. The validation was to enhance the quality of the instrument, thus the content validity. The recommendations of the experts were considered and the questionnaire was modified accordingly. The Validation was done to prevent errors and make sure that the instrument measured what it was supposed to measure and the data collection and measurement procedures work as it has been intended for by the researcher (Ragin \& Amoroso, 2011).

\section{Results and Discussion}

\subsection{Demographic Characteristics of respondents}

Table 2 displays the socio-demographic characteristics of respondents participated in the study. The majority of the participants (about 57\%) were between 26 and 35 years while about $38 \%$ were 35 and above, and, only $5 \%$ of the participants aged between 18 and 25 years (Table 2). 
Table 2: Demographic characteristics of respondents

\begin{tabular}{|c|c|c|c|}
\hline Demographic variable & & $\mathrm{f}$ & $\%$ \\
\hline \multirow{5}{*}{ Age } & $18-25$ years & 3 & 5.2 \\
\hline & 26-35 years & 33 & 56.9 \\
\hline & & & \\
\hline & 35 years and above & 22 & 37.9 \\
\hline & Certificate & 20 & 34.5 \\
\hline \multirow[t]{5}{*}{ Level Of Education } & Diploma & 27 & 46.6 \\
\hline & Degree & 9 & 15.5 \\
\hline & Others & 2 & 3.4 \\
\hline & Finance & 27 & 46.6 \\
\hline & Education & 15 & 25.9 \\
\hline \multirow[t]{5}{*}{ Department } & Procurement & 4 & 6.9 \\
\hline & Health & 2 & 3.4 \\
\hline & Agriculture & 6 & 10.3 \\
\hline & Transport & 4 & 6.9 \\
\hline & Less than 2 years & 11 & 19 \\
\hline \multirow{3}{*}{$\begin{array}{l}\text { Work Experience (length of } \\
\text { service) }\end{array}$} & $3-4$ years & 4 & 6.9 \\
\hline & Above 5 years & 43 & 74.1 \\
\hline & Yes & 56 & 96.6 \\
\hline \multicolumn{4}{|l|}{ Does Your Work Involve Gabs } \\
\hline & No & 2 & 3.4 \\
\hline
\end{tabular}

This shows that most of the respondents $(95 \%)$ were in the middle age group and above. The employees' education and experience influence the situational judgment of their work environment influenced their attitude and perception towards the implementation of GABS in 


\section{Mll Macrothink}

International Journal of Accounting and Financial Reporting ISSN 2162-3082 2017, Vol. 7, No. 1

the public sector of Botswana (Tarmidi, et al, 2013). Therefore, these two demographic factors were considered important for this study. A high proportion of the respondents were diploma and certificate holders at about $47 \%$, while less than half of the participants indicated that they had university degree $15.5 \%$. In addition, $3.4 \%$ of the participants revealed that they have other qualifications such as Association for Accounting Technicians (ACCA), Association for Accounting Technicians (AAT) and Chartered Institute of Management Accountants (CIMA).

Majority of participants who were already using the system for data capturing and reporting were from Finance department (50\%), followed by the Education department 13\%), Transport, Agriculture and procurement and logistics (10\%) each, and the lowest of at $7 \%$ for Health Department. These findings showed that despite the introduction of GABS in Botswana, there is disparity in its application and usage in Government ministries. For instance, health department has the least number of employees that effectively use GABS to promote government business in Botswana. This is attributed to the fact that the system was newly introduced in the ministry. The results showed that a larger percentage of respondents at about $74 \%$ indicated that they had served for five (5) or more years in public service, while $19 \%$ cited that they have less than two (2) years working experience in public service. However, around $7 \%$ of the respondents indicated that they had served for 3 to 4 years in public service (Table 2). The length of service may influence the application of GABS system and its effectiveness in the public service of Botswana. Public service employees who participated in the study were asked to indicate whether their work involved the use of GABS either directly or indirectly. Almost all officers interviewed (about 97\%) indicated their work involved the use of GABS. Only 3\% said they were not frequently using the system mainly due to lack of resources such as; computers (Table 2).

\subsection{Implementation and Benefits of Government Accounting and Budgeting System}

Research Question 1: Does the government accounting and budgeting system benefits users in the public sector of Botswana?

Descriptive statistics was used to analyze this research question investigated the benefits of Government Accounting and Budgeting System in the public service of Botswana. Table 3 presents information on the benefits of the application of GABS. Findings revealed that $66 \%$ of the respondents indicated that the system improved their work rate by stating that the system promotes information management, time saving, budget control, financial monitoring, system improvements, cost reduction and internal controls (Table 3). They also reported that the system allowed for fast payment of clients, automatic budget updates, security, payment of missionaries and proper reporting of government financial statement. The findings of the qualitative analysis complemented the quantitative analysis by suggesting that the introduction of GABS improved service delivery in areas such as working conditions, government fiscal policy, information management, data sharing, electronic financial statements, easy payments and service standards. While the findings revealed that majority of the participants agreed that the introduction of GABS is beneficial tithe public service of Botswana, it was also reported that approximately $28 \%$ of the participants do not see the 


\section{Macrothink}

International Journal of Accounting and Financial Reporting

ISSN 2162-3082

2017, Vol. 7, No. 1

benefit that GABS brings to public service of Botswana. The participant, they argued that the system caused misunderstanding between clients and institutions in the following manner: delay in payments, lack of network service, bureaucratic bottleneck in government programmers, lack of internal controls and unauthorized access to information by users. On the other hand, few participants, i.e., (approximately 7\%) were undecided on whether introduction of GABS is beneficial or not to Botswana public service. The participants see the introduction of computerized accounting system as too cumbersome. They also felt that the system made it difficult for finance department to operate freely as it hindered the process of government transactions, and could pose a danger in the use of manual system in the future.

The finding also indicated that, the introduction of automated system limits the use of manual system by delaying client's payments when the system encounters problems. The participants also argued that the system entails bureaucratic bottleneck, as it involved a lot of approval before any payment could be done. The respondents also mentioned staff shortage which they said, resulted in some officers doing multi-tasks, even going extra mile and do the work they had not been trained for. However, the findings showed that about 16 percent of the respondents were not sure if it was a good move that government opted for automated system. Putting together, these findings showed that some employees are still trying to adjust to or understand the complete function of the system. It also suggests that on average majority of the respondents who participated in the current study indicated their support forth government's introduction of computerized GABS in the public service.

Table 3: Knowledge on Government Accounting and Budgeting System among the respondents

Variables Number $\quad \%$

Do you think the introduction of GABS was a good idea?

Yes

No

Does GABS have benefits?

Yes 
No

Not sure

If yes, what are the benefits?

Time saving

Reduced paper work \& load

Cost sharing

Reduced error incidences
Has GABS brought an improvements to service delivery?

Yes

No

Not sure
10.3

Government Accounting and Budgeting System has been identified as critically important to financial transaction in organizations (Ahab, 2003). Previous findings proved that GABS creates opportunity to record and process financial transactions and also permits managers and other end users to analyze the financial health of an organization and take necessary actions in light of the information received (Wahab, 2003). The findings of the current study supported this assertion by reporting that introduction of computerized GABS in the public sector of Botswana is a good step, that promotes efficiency in government service. This finding aligned with other studies (Marivic, 2009; Meigs et al, 1998; Wahab, 2003) reported that implementation of computerized GABS saved time, minimized theft, improved data management, reduced fraud, tax evasion, manual writing of payments, managed air distribution of resources and promotes service efficiency in public sector. The findings of this study aligned with this assertion by establishing that the introduction of GABS benefits users, compared to the traditional/manual based system. The benefits reported in this study include: high productivity, accuracy, time savings and management of organizational finance. This finding aligned with previous study on GABS that suggested government accounting and budgeting system as more beneficial to organization than manual system (Marvin, 2009). The result also supported the findings of Lewis and Pen drill, (1999), who argued that, employees who have access to government accounting and budgeting system are more proficient in their 


\section{Ml Macrothink}

International Journal of Accounting and Financial Reporting ISSN 2162-3082 2017, Vol. 7, No. 1

work and enjoy high productivity. Thus, it can be concluded that GABS allows employees to be dynamic in their work, as it offers them the opportunity to adjust and make changes faster in their duties.

Although, the findings of study reported that the introduction of GABS benefits employees in the public sector as the majority of respondents (48\%) beliefs that the system promotes service delivery. However, significant number of participants $(81 \%)$ with contrary opinion based their argument on the following points: the system delayed payments, lack of network service to support its operation, bureaucracy in processing government eradication support programmes, lack of internal controls and unauthorized access to information by users. This finding aligned with other studies (Meigs, 1986; Nash \& Healy, 2003; Tarmidi et al., 2013 \& Wahab, 2003) to establish that GABS promote errors, improper human intervention and distortion of information that is essential for decision making. However, despite these views, the study concluded that employees' attitude and knowledge of GABS influenced their beliefs on its effectiveness, and motivated their commitment to the process.

\subsection{Perception of Employees on the effectiveness of Government Accounting And budgeting system}

Research Question 2: What are the perceptions of users on the effectiveness of Government Accounting and Budgeting System in the public sector of Botswana?

To answer this research question, a correlation analysis was conducted and results are presented in Table 4. This analysis was conducted to determine the relationship between the introduction of GABS by the government of Botswana and the perceptions of employees in the Botswana public sector. The results showed that at statistical value of $0.01(p=0.01)$, a significant positive relationship was established between employees' perception on the effectiveness (such as benefits of GABS to users, improvement in service delivery) and introduction of GABS in public service of Botswana. A strong and positive relationship was established between employees perception of GABS, improvement of service delivery, and achievement of GABS $(\mathrm{r}=0.542, \mathrm{p}<0.01)$. Also a moderate, positive relationship was reported between employees perceptions of the introduction of GABS and benefits to users ( $r=0.419$, $\mathrm{p}<0.01)$ and improvement in service delivery $(0.422, \mathrm{p}<0.01)$. However, the relationship between employees perceptions of introduction of GABS and GABS achieving its intended objectives was statistically insignificant $(\mathrm{p}>0.01)$ indicated that there is a weak relationship between employees' perceptions of GABS and GABS achieving its intended objectives.

Qualitative findings also revealed that majority of the participants confirmed that they were aware of the introduction of computerized GABS in their departments. However, majority of the participants argued that the system has not achieved its intended objectives in the public service. Therefore, the findings (quantitative and qualitative), can be deduced by suggesting that the introduction of computerized GABS had not yet achieved its intended objectives in the public sector of Botswana based on the reasons including lack of resources, Unfair distribution of resources, Service standards not met and Poor Customer Service.

Table 4: Relationship between Employees' Perception on the effectiveness of Government 
Accounting and Budgeting System

\begin{tabular}{|c|c|c|c|c|}
\hline Kendall's tau correlation & & $\begin{array}{l}\text { benefits of } \\
\text { GABS to } \\
\text { users }\end{array}$ & $\begin{array}{l}\text { improvement } \\
\text { in service } \\
\text { delivery }\end{array}$ & $\begin{array}{l}\text { GABS } \\
\text { achieved } \\
\text { objectives }\end{array}$ \\
\hline \multirow[t]{3}{*}{ Introduction of GABS } & $\begin{array}{l}\text { Correlation } \\
\text { Coefficient }\end{array}$ & .419 & .422 & .143 \\
\hline & Sig. level & .001 & .001 & .274 \\
\hline & $\mathrm{N}$ & 58 & 58 & 58 \\
\hline \multirow[t]{3}{*}{ Benefits of GABS to users } & $\begin{array}{l}\text { Correlation } \\
\text { Coefficient }\end{array}$ & & .400 & .475 \\
\hline & Sig. level & & .001 & .000 \\
\hline & $\mathrm{N}$ & & 58 & 58 \\
\hline \multirow[t]{3}{*}{$\begin{array}{l}\text { Improvement in service } \\
\text { delivery }\end{array}$} & $\begin{array}{l}\text { Correlation } \\
\text { Coefficient }\end{array}$ & & & .542 \\
\hline & Sig. level & & & .000 \\
\hline & $\mathrm{N}$ & & & 58 \\
\hline
\end{tabular}

The current study investigated employee's perceptions on the implementation of GABS in Botswana. The findings showed that there is a positive significant relationship between the introduction of GABS and employees' perception on the benefits and improvement of service delivery in Botswana. However, moderate significant relationship was established between introduction of GABS and employee's perception on attainment of its intended objective. These results was corroborated in the qualitative findings, as majority of the participants $(57 \%)$ who participated in the interview believed the GABS had not achieved its intended objectives in the public service of Botswana. However, some few participants (43\%) had some contrary opinion by stating that the system achieved its intended objectives by promoting efficiency in government services. Taking together, however, the findings (i.e., quantitative and qualitative) aligned with other studies (Elekwa \& Innocent, 2013; MFDP Report, 2007; Wahab, 2003; Wood\& Sangster, 1999) that reported mixed findings on 


\section{Al Macrothink}

International Journal of Accounting and Financial Reporting ISSN 2162-3082 2017, Vol. 7, No. 1

employees' perceptions of GABS in public sector. For instance, Elekwa and Innocent (2013); Wood and Sangster (2009) reported that employees perceived GABS as increased service delivery. They also believed the system allowed managers to identify and solve problems instantly. However, the report of MFDP (2007) revealed that employees doubt their capability to function within the system operation, and this influenced their views on its success. Similarly, Wahab (2003) reported that the experience of employees coupled with their social environment influenced their perception on GABS. For instance, he cited the problem of network which employees perceived as obstacle to successful implementation of GABS. Overall, the mixed findings on employee's perceptions of GABS could be attributed to their general beliefs that the implementation of the system needs to be redefined in order to promote its efficiency in the public sector of Botswana.

The interviews with respondents were thematically coded and the major hindrances in the effectiveness of GABS are presented as follows.

Lack of resources: The use of computerized system has increased the use of computers in the public sector which resulted in high government expenditure. According to the respondents, the increase in use of computers limited government spending; therefore, very few computers were bought for various departments. This caused dissatisfaction among employees lowering the moral down which impacted the effectiveness of GABS negatively. Lack of qualified employees was also mentioned as one of the factor that hinders the effectiveness of GABS as replacement of retired officers and those who left service for any other reasons resulted in shortage of staff which leads to poor service delivery by the government departments.

Unfair distribution of resources: The participants also expressed that unequal distribution of government resources impacted on the efficiency of GABS. They buttressed this by stating that employees who are not using GABS (non-accounting officers) were allocated computers and other devices that aided the system, while those working directly with the system were not allocated the resources needed to boost their jobs. This unfair distribution of resources led to poor service delivery. Moreover, some respondents also expressed that shortage of system administrators who manage the system server directly departments which affects the application of GABS. They stated that some departments employed system administrators to help them adjust to technical aspect of their work, while other departments do not have such personnel to assist them with technical problems. This caused problems as few system administrators had to shuttle from one department to the other, which in most cases resulted in the delay of work.

Service standards not met: Majority of the respondents expressed that service standards were not met due to network problem. The governments' main aim is to take services directly to people which most clients were not getting. Some departments (such as agriculture) were unable to help clients in time due to shortage of staff. Majority of users who were mostly administration officers and supplies officers said centralization of funds allocated to the ministry pose a big problem. This was due to bulky work in the ministry headquarters which delayed the processing of funds done by few staff, thus transferring funds to regions was delayed. This also affected some farmers who were to be assisted by government schemes 
such as livestock management and infrastructure development as they were not assisted in time.

Poor Customer Service: Respondents mentioned poor customer service as one of the factors that impact on the effectiveness of GABS. They believed that due to shortage of trained staff to implement the system, services were delayed and there was an increase in some staff workload. They further highlighted that just like any system, GABS had its own shortfalls especially that it had to spread all over the government departments in the country. In their view, they indicated that some of its achievement was that it had been installed in almost all government departments, and majority of users were trained to use it including accounting officers in remote areas, except that physical resources were not available for some officers to perform the job. Respondents further said some departments not yet connected to the system and they have not been assisted by their regional district office due to shortage of physical resources with them. They also indicated the system allows operators to track back records without any struggle.

\subsection{Challenges in the application of computerized Government Accounting and Budgeting System}

Research Question 3: What are the challenges in the application of government accounting and budgeting system in the public sector of Botswana?

Descriptive statistics in form of percentage was used to analyze this research question and the results are presented in Figure 1. About $69 \%$ respondents indicated that shortage of skilled manpower was a serious challenge in the system. Approximately 93\% respondents said network was a serious challenge to the successful implementation of GABS. Roughly $24 \%$ of the respondents felt that theft was a challenge and it affects the successful and effective implementation of GABS (Figure1). In addition, about $40 \%$ of the total respondents revealed that viruses has been a serious challenge and may influence a successful implementation of GABS. While approximately $14 \%$ of the respondents felt that accessing of the system data by outsiders (hacking) may be a challenge to the success and effective implementation of GABS. Furthermore, $28 \%$ of the respondents observed that sharing of passwords by users has been a challenge to the implementation of GABS as some officers do not see sharing of these passwords as a problem, while $19 \%$ of the respondents revealed that unauthorized access of the system by non-users may arise and lead to the ineffectiveness of GABS. The findings from the qualitative analysis revealed that, some employees deliberately ignore the importance of passwords. This was evident in the response given by the participants, as majority was of the opinion that application of GABS is cumbersome. One participant put it succinctly:

"During our training, trainers emphasized no sharing of passwords, but some of us are just doing it especially in offices where there are many temporary staffs, we need their assistance, sometimes due to trust you have in them and the fact that you want the job to be done in time, you ended up giving them your password to use".

Interestingly, this study showed that, the introduction of computerised GABS faced a lot of 


\section{Mll Macrothink}

International Journal of Accounting and Financial Reporting

ISSN 2162-3082

2017, Vol. 7, No. 1

challenges in the public sector. Though, earlier research affirmed that computerised GABS is vital for organizational efficiency and development (Wahab, 2003), this was not found the case in Botswana, as implementation of GABS is hindered by different factors. The review of literature on GABS (i.e., Nash \& Healy, 2003; Wahab, 2003), and the findings of this study, linked poor implementation of GABS in the public sector to service standards and unfair distribution of resources. For instance, it was affirmed in the current study that lack of resources, service standards and unfair distribution of resources hindered the effectiveness of GABS. The study also aligned with the findings of studies (Nash \& Healy, 2003; Tarmidi et al., 2013) to suggest a lack of manpower and limited capital resources as contributing to poor implementation of GABS. This was confirmed in the present study, as limited government expenditure coupled with lack of qualified staff hindered an effective implementation of GABS in Botswana.However, this could be attributed to a number of factors such as organizational structure, lack of manpower, limited expenditure to support the implementation and, attitude of employees towards change to a new system

Figure 1: Challenges in the application of Government Accounting and Budgeting System

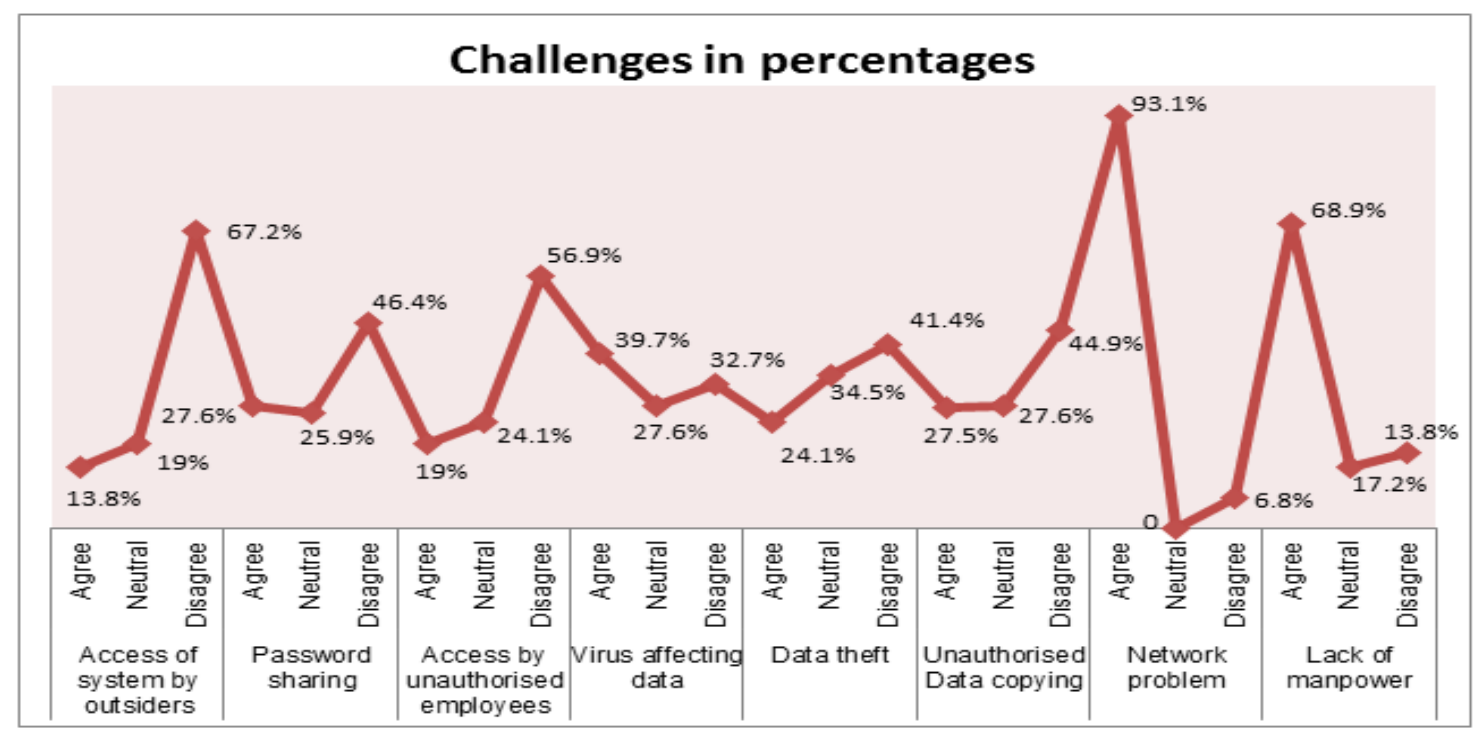

The triangulation of the findings of the quantitative and qualitative data showed lack of employees' empowerment as a contributing factor to the challenges facing the introduction of computerized GABS in the country. Overall, the expectations that employees have about GABS coupled with the inherent problems that comes with its application influenced its effectiveness in Botswana. Finally, it can be concluded by suggesting that the above factors mediate the effectiveness of computerized GABS in the public sector of Botswana. However, through empowerment, employees can develop necessary skills and knowledge required to manage the challenges that come with GABS, and contribute to the goals and objectives of their organization. 


\section{1l Macrothink}

International Journal of Accounting and Financial Reporting

ISSN 2162-3082

2017, Vol. 7, No. 1

4.6 Strategies to Improve Computerized Government Accounting Budgeting System

Research Question 4: What are the strategies can be adopted to improve the effectiveness of Government Accounting and Budgeting System in the public sector of Botswana?

Descriptive statistics and interviews were conducted to analyze the employee's views on the strategies that can be employed to improve the effectiveness of GABS in the public sector of Botswana (Table 5). Majority of the respondents (65.5\%) followed by increase in training (47\%) suggested an increase in skilled and qualified personnel as a way of promoting effectiveness of GABS in the public sector, while $16 \%$ of the respondents suggested installation of effective power and data back-up systems as a strategy for improving the administration of the system, In addition, $47 \%$ of the respondents indicated that establishment of a constructive informative educational out-reaches would promote and increase public awareness on GABS (Table 5).Overall, these findings revealed that through proper education and planning, government can promote and sustain GABS as a tool for effective service delivery in the public sector.

Table 5: Strategies to improve the effectiveness of Government Accounting and Budgeting system

Strategies to improve the effectiveness of GABS $\mathrm{f} \%$

Increase in qualified personnel

Provision of training on the GABS

Decentralization of Physical Resources

Provision of no password sharing

Ensuring reliable back -ups system

Installation of power back - ups
3865.5

2746.6

2541.5

2541.5

2339.7

915.5

Despite these obstacles and shortfalls on implementation of GABS, the system still has great potential to achieve its intended objectives and benefits in public sector of Botswana. Based on the above, this study suggests the following: an increase in qualified personnel, installation of power back-ups, and creation of reliable back-up systems, constant public awareness and decentralization of physical resources as strategies that can be employed to improve its effectiveness in Botswana. For example, an increase in skilled and qualified personnel across board would promote the effectiveness of GABS in the public sector of Botswana. Further, development of the energy sector and proper management of information would improve and promote proper administration of the system in government ministries. Lastly, constant and constructive informative educational out-reaches by the government to promote and increase public awareness on the importance of GABS to the users. 


\section{Macrothink \\ International Journal of Accounting and Financial Reporting \\ ISSN 2162-3082 2017, Vol. 7, No. 1}

\section{Conclusion and Recommendations}

This study investigated the effectiveness of Government Accounting and Budgeting System (GABS) in the public sector of Botswana. The results revealed that government accounting and budgeting system have benefited the public sector of the country. These benefits include high work rate, increase in productivity, improvement in accuracy, time saving and cost reduction. On the other hand, the study showed that employees had mixed perceptions on the implementation of GABS, as majority believed the system has not achieved its intended objectives in the public sector of Botswana. The results suggested that implementation of GABS in Botswana is facing some challenges and this hindered its effectiveness of the systems as well as government services. Overall, the study suggests that an increase in qualified personnel, constant energy supply and consistent public awareness would improve the effectiveness of GABS in the public sector of Botswana.

The following recommendations were mad to the stakeholders in the public sector to enhance the effectiveness of GABS.

1. Government should organize training and development for their employees, particularly in technical areas, i.e., Skills Development, Information Technology (IT) and Customer service.

2. There is need to sensitize GABS stakeholders on the system, its operations, intended objectives and possible challenges/delays. This will also promote cordial existence among GABS stakeholders at large.

3. There is need for constant research on GABS progress or lack thereof. Conducting this research has proved that, there is very little research on this subject matter hence the need and opportunity for researchers to generate more information in this regard.

4. Physical resources should be decentralized in government departments enabling each ministry to take appropriate measures to provide physical resources to officers in remote areas.

5. As a limited number of government departments were involved in this study therefore, future research should include employees from other government departments in the country so that the findings can be better generalized for the public sector.

\section{References}

Alhosban, A. A., \& Maqableh, A.M. (2014). The Role of Computerized Accounting

Information inProduct Pricing and Cost Measurement in Jordanian Industrial Corporations. International Journal of Sciences, 27, 2307- 4531.

Barton, A. (2009). The use and abuse of accounting in the public sector financial management reform program in Australia. Abacus, 45 (2), 221- 248

Batt, K. (2014). Acquisition, Leadership, Project Management Tech. Budgeting 
process challenges and steps to start solving them. Retrieved February 15, 2015 fromhttps://www.govloop.com/.../5-budgeting-process-challenges-and-steps-t...

Carl, S. W., Wailes, J.M.,\& Fess, P.E. (1999).Financial Accounting $\left(7^{\text {th }}\right.$ ed).

United States of America: Thomson Publishing Company.

Carol, L. C. (2002).How Computers has Simplified Accounting. Retrieved October, 2, 2014 from http://www.yale.edu

Chan, J. L. (2001).Global Government Accounting Principles. Working paper University of Illinois, Chicago

Creswell, J. W., Plano Clark, V. L., Gutmann, M. L., \& Hanson, W. E. (2008). An expanded typology for classifying mixed methods research into design. In V.L.

Plano Clark \& J. W. Creswell (Eds.), The Mixed Methods Reader (pp.159-197).

Dalci, I. \& Tanis N. V. (n.d), Benefits of Computerized Accounting Information Systems on The JIT Production Systems, Computerized Accounting, p.35.

Doost, R.K. (1984). Public versus Private Budgeting. A comparative study. The Government Accountants Journal: Fall, 47- 57.

Elekwa, N. N. \& Innocent, E. O. (2013). An analysis of computerized accounting and Payrollingsystem on monthly emolument in Nigerian Local Government . International Journal of Accounting Research. 1(3) .

Government Accounting Standards Board (1997). Accounting and Financial Reporting for Certain Investments and for External Investments Pools. Statement No. 31

Harwell, M. (2011). Research Design in Qualitative/quantitative/mixed methods. In Conrad C. \&Serlin, R. (eds). The SAGE handbook for research in education: Pursuing ideas as the keystone of exemplary inquiry $\left(2^{\text {nd }}\right.$ ed. pp.147-165). Thousand Oaks, CA: SAGE Publications.

Hingarh, V.,\& Ahmed, A. (2013). Understanding and Conducting Information Systems Auditing. Wiley.

Ilias, A., \& Zainudin, N. N. B. (2013). Factor Affecting the Computerised Accounting System Usage in Public Sector, Journal of Internet Banking and Commerce. 18 (1).

Indira, A. (2008). Government Accounting System. Retrieved September, 28, 2014 from http://www.indianmba.com/faculty_column/fc584/fc584.html

Institute of Internal Auditors (2011). Supplemental Guidance: Public Sector Definition $\begin{array}{lll}\text { Retrieved } & \text { March } & 2016\end{array}$ fromhttps://na.theiia.org/...guidance/Public\%20Documents/Public\%20Sector

International Federation of Accountants (2000). Financial Reporting under the cash bases of accounting. Exposure draft 9, Public Sector Committee, New York 


\section{Ml Macrothink}

International Journal of Accounting and Financial Reporting

ISSN 2162-3082

2017, Vol. 7, No. 1

International Public Sector Accounting Standards Report (1997). Evaluating the Security of Computerized Accounting Information System. United Kingdom: Aberdeen University.

International Public Sector Accounting Standards Board Report (1993).Guide to Computerizing your Accounting System. Retrieved September 20, 2014 from http://www.erc.msh.org/mainpage.cfm?

International Public Sector Accounting Standards (2011). Impacts and Compliance aspects, SAP. Retrieved May 25, 2016 from

http://www.sap.com/bin/sapcom/en_gb/downloadasset.2009-03-mar-06-14.internationalpublic-sector-accounting-standards-ipsas--impact-and-compliance-aspects-pdf.html

Ismail, S. A., Saleh, N. M. \& Kundari, S. (2012). Computerized Accounting System at The MARA State Offices. International Journal of Research in Management \& Technology, 2(6), $2449-9563$

Johnson, R. B., Onwuegbuzie, A. J., \& Turner, L. A. (2007). Toward a definition ofmixed methods research. Journal of Mixed Methods Research, 1(2), 112-133.

Lewis, R., \& Pendrill, D. (1999). Advanced Financial Accounting, (4 ${ }^{\text {th }}$ ed.). London: Pitman.

Lincoln, Y. S., \& Guba, E. G. (2000). Paradigmatic controversies, contradictions, and emerging confluences. In N. K. Denzin, and Y. S. Lincoln (Eds.), Handbook of qualitative research (pp. 163-188). Thousand Oaks, CA: Sage

Manani, I. (2013). Impact of computerization on Internal Control over Cash in Municipal Councils in Tanzania: A case of Iringa Municipal Council. Research Journal of Finance and Accounting, 4(2).

Marivic, A. (2009). Evaluating the Security of Computerized Accounting Information Systems. An empirical study on Egyptian Banking Industry, PhD Thesis. Aberdeen University, UK.

McBride, P. (2000). Guide to Computerizing your Accounting System. Retrieved on September20, 2014 from http://www.erc.msh.org/mainpage.cfm?

McRae, T.W. (1998). Computers and Accounting (1 ${ }^{\text {st }}$ ed.). Great Britain: Pitman Press Bath.

Meigs, F. R., \& Mary, A. (1998).Financial Reporting $\left(9^{\text {th }}\right.$ ed). United States of America: Irwin McGraw hill publishers.

Michael, E. P., \& Miller .V. E. (2005). How Information Gives Competitive Advantage.Retrieved September 26, 2014 from www.pcad.ac

Mihir, B. (2002). Financial Accounting ( $3^{\text {rd }}$ ed.).New York: Heinemann Publishers.

Ministry of Finance and Development Planning. (2007). A Performance Audit Report on Government Accounting. Gaborone, Botswana: The Office of the Auditor General. Retrieved 
April 16, 2015 from https://afrosai-e.org.za/sites/afrosai-e.org.za/files/../Government_0.pdf

Ministry of Finance and Development Planning. (n.d). Public Finance Management (PFM) Reform Programme for Botswana from www.africanbondmarkets.org/.../Botswana/...Finance...planning...Botswana.

Monteiro, B.R.P., \& Gomes R.C. (2012). The International Experience with Accrual Budgeting in Public Sector. Retrieved September 24, 2015 from www.scielo.br/pdf/rcf/v24n62/en_02.pdf

Motsamai, M. (2014, September 22). Botswana commits to IPSAS. Botswana Daily News, $B O P A$. Retrieved from www.dailynews.gov.bw/mobile/news-details.php?nid=14676\&flag=

Nash, F. J., \& Healy, C. (2003). Accounting Information Systems ( $2^{\text {nd }}$ ed.). London

Nobes, C. (1988). In Historical-Comparative Perspective of Governmental Accounting, p.202).

Okoye, E. I. \& Oghoghomeh. (2011). The impact of computerized accounting system on external audit functions.

Patel, S.B.P. \& Sahajan, S. (2015). Effect of Accounting Information System on Organizational Profitability. International Journal of Research and analytical Review, 2(1), $1248-1269$.

Pendlebury, M. (2000). Public Sector Accounting (5 $5^{\text {th }}$ ed.), London: Pitman.

Ragin, C. C., \& Amoroso, L. M. (2011).Constructing Social Research (2 ${ }^{\text {nd }}$ ed.). London: SAGE Publications.

Robinson, M. (2009). Accrual budgeting and fiscal policy. Journal on Budgeting, (1), 1- 29.

Saunders, M., Lewis, P., \& Thornhill, A. (2000). Research Methods for Business Students ( $2^{\text {nd }}$ ed.).Pearson Education. Prentice Hall

Saunders, M., Lewis, P., \& Thornhill, A. (2007). Research Methods for business students ( $4^{\text {th }}$ ed.).Pearson Education. Prentice Hall

Sindhu, A. (2012), Research Methodology - Shodhganga. Retrieved April 14, 2016 from http://shodhganga.inflibnet.ac.in/bitstream/10603/3704/12/12_chapter\%202.pdf

Tarmidi, M., Rashid, A. A., Deris, M.S., \& Roni, R.A. (2013). Computerized Accounting System Threats in Malaysian Public Services, International Journal of Finance and Accounting, 2(2), 109-113.

Teddlie, C., \& Tashakkori, A. (2009). Foundations of mixed methods research: Integrating quantitative and qualitative approaches in the social and behavioural sciences. Thousand Oaks, CA: Sage Publications.

Tijani, O. M., \& Mohammed, A. K. (2013). Computer-Based Accounting Systems in Small and Medium Enterprises: Empirical Evidence from a Randomized Trial in Nigeria. Universal 


\section{Macrothink \\ International Journal of Accounting and Financial Reporting \\ ISSN 2162-3082 2017, Vol. 7, No. 1}

Journal of Management

Van, B. (2005).Introduction to Accounting. New Delhi: Vikas publishing House.

Wahab, A. (2003). An approach to Accounting ( $2^{\text {nd }}$ ed.). United States of America:Irwin McGraw Hill Publishers. Retrieved November 8, 2024 from http://www.dailynews.gov.bw/mobile/news-

details.php?nid=14676\&flag=www1.worldbank.org/publicsector/pe/befa05/Executionaccrual .doc

Wildavsky, A. (1984). The Politics of budgetary Process, $\left(4^{\text {th }}\right.$ ed), Little, Brown and Co. Boston, Mass

Wiley, C. (2013). Government accountant. Retrieved November 5, 2014 fromhttp://www.accountingedu.org/government.html

Wood, F., \& Sangster, A. (2012). Business Accounting I, (12 ${ }^{\text {th }}$ ed.), Britain, Financial Times Prentice Hall

Yount, R. (2006). Research Design and Statistical Analysis for Christian Ministry(4 ${ }^{\text {th }}$ ed.).Retrieved December 15, 2014 from http://www.napce.org/

\section{Copyright Disclaimer}

Copyright for this article is retained by the author(s), with first publication rights granted to the journal.

This is an open-access article distributed under the terms and conditions of the Creative Commons Attribution license (http://creativecommons.org/licenses/by/3.0/). 